\section{6 OPEN ACCESS}

\title{
Evidence review of hydroxyurea for the prevention of sickle cell complications in low-income countries
}

\author{
Mercy Mulaku, ${ }^{1,2}$ Newton Opiyo, ${ }^{3}$ Jamlick Karumbi, ${ }^{1,2}$ Grace Kitonyi, ${ }^{4}$ \\ Grace Thoithi, ${ }^{1,2}$ Mike English ${ }^{2,5}$
}

Additional material is published online only. To view please visit the journal online (http://dx.doi.org/10.1136/ archdischild-2012-302387).

${ }^{1}$ School of Pharmacy, University of Nairobi, Nairobi, Kenya

${ }^{2}$ SIRCLE Collaboration, KEMRIWellcome Trust Research Programme, Nairobi, Kenya ${ }^{3}$ KEMRI-Wellcome Trust Research Programme ${ }^{4}$ Hematology and Blood Transfusion Unit, School of Medicine, University of Nairobi, Nairobi, Kenya

${ }^{5}$ Nuffield Department of Medicine, University of Oxford, Oxford, UK

\section{Correspondence to} Dr Mercy Mulaku, KEMRIWellcome Trust Research Programme, P.O. Box 43640, Nairobi 00100, Kenya; mmulaku@nairobi.kemriwellcome.org

Received 23 May 2012

Revised 2 April 2013 Accepted 8 August 2013

Published Online First 30 August 2013

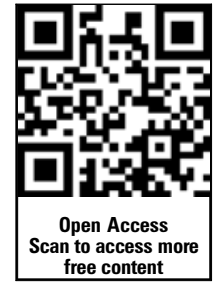

To cite: Mulaku M, Opiyo N, Karumbi J, et al. Arch Dis Child

2013:98:908-914.

\section{ABSTRACT}

Hydroxyurea is widely used in high-income countries for the management of sickle cell disease (SCD) in children. In Kenyan clinical guidelines, hydroxyurea is only recommended for adults with SCD. Yet many deaths from SCD occur in early childhood, deaths that might be prevented by an effective, disease modifying intervention. The aim of this review was to summarise the available evidence on the efficacy, effectiveness and safety of hydroxyurea in the management of SCD in children below 5 years of age to support guideline development in Kenya. We undertook a systematic review and used the Grading of Recommendations Assessment, Development and Evaluation system to appraise the quality of identified evidence. Overall, available evidence from 1 systematic review ( $n=26$ studies), 2 randomised controlled trials ( $n=354$ children), 14 observational studies and 2 National Institute of Health reports suggest that hydroxyurea may be associated with improved fetal haemoglobin levels, reduced rates of hospitalisation, reduced episodes of acute chest syndrome and decreased frequency of pain events in children with SCD. However, it is associated with adverse events (eg, neutropenia) when high to maximum tolerated doses are used. Evidence is lacking on whether hydroxyurea improves survival if given to young children. Majority of the included studies were of low quality and mainly from high-income countries. Overall, available limited evidence suggests that hydroxyurea may improve morbidity and haematological outcomes in SCD in children aged below 5 years and appears safe in settings able to provide consistent haematological monitoring.

\section{INTRODUCTION}

It is estimated that $7 \%$ of the world's population are carriers for haemoglobin disorders (sickle cell anaemia (SCA) and thalassaemia) and between 300000 and 500000 infants with the severe heterozygous forms of these diseases are born each year. ${ }^{1}$ Sickle cell disease (SCD) is the most important potentially devastating, recessively inherited condition. The well-described protective effect of sickle cell trait on mortality from malaria, and consequentially from serious bacterial diseases, ${ }^{2}$ has resulted in high prevalence of this gene disorder in many African countries. In SCD, deformation of red blood cells ('sickling') and vaso-occlusive phenomena are characteristic and result in pain, tissue injury and haemolysis. ${ }^{3}$ Disease severity varies widely but overall mortality is substantially increased and life expectancy decreased when compared with the general population. Despite the availability of effective treatments for improving clinical outcomes of SCD, mortality is high in

\section{What is already known on this topic?}

- Hydroxyurea represents the only widely used drug which modifies sickle cell disease (SCD) pathogenesis.

- In adults hydroxyurea has transformed the treatment of SCD and is associated with decreases in hospitalisations, acute chest syndrome episodes and painful crises and improved quality of life.

\section{What this study adds}

Evidence on potential benefits of use of hydroxyurea on children below 5 years with SCD is that it is associated with decreased pain crises and dactylitis.

- Contextual issues of a low-income country like Kenya that may influence recommendation for use of hydroxyurea in children with SCD.

children aged between 6 months and 3 years in Africa, ${ }^{4} 5$ often before confirmatory diagnosis in such settings. Early detection and intervention may reduce this high burden of disease.

Treatment of patients with SCD is largely supportive with hydroxyurea (HU) representing the only widely used drug which modifies disease pathogenesis. It improves clinical outcomes by increasing fetal haemoglobin $(\mathrm{HbF})$, which in turn reduces risks of 'sickling' events. In adults, it is associated with decreases in hospitalisations, acute chest syndrome episodes and painful crises, and improved quality of life. ${ }^{6}$ It was approved by the US Food and Drug Administration for treatment of SCD in adults in 1998 and has also become widely used for management of children with SCD in high-income countries. $^{7}$

In Kenya, current clinical guidelines recommend HU only for adults who present with more than three sickle cell crises in a year. For children only supportive care (analgesics, supplementary folic acid and malaria prophylaxis when travelling to malaria endemic zones, penicillin prophylaxis and blood transfusion whenever necessary) is necessary. ${ }^{8}$ To help update clinical recommendations for care of children below 5 years of age with SCD in Kenya, we conducted a review of the available evidence on the effectiveness and safety of HU, 
compared with standard supportive care, on SCD-related mortality and morbidity. As making practice recommendations requires consideration of the quality of research evidence and local context, we also highlight contextual issues likely to be of importance to Kenya and countries with similar health systems challenges.

\section{METHODS}

\section{Search strategy}

A standard search was performed in the Cochrane Library, MEDLINE (using the PubMed clinical query filters), ${ }^{9}$ and one clinical trials registry (http://clinicaltrials.gov). Reference lists of identified relevant articles were scanned to identify additional studies for inclusion. The search terms used were: (child OR neonate OR newborn OR infant) AND (SCD OR SCA) AND (HU OR hydroxycarbamide). No language limits were applied. Having identified a well-conducted systematic review published in December 2008, ${ }^{7}$ we restricted our search to studies published between January 2007 and March 2012 to supplement the findings of the existing review. Our purpose was not, however, to formally update this systematic review.

\section{Study selection criteria}

Studies with more than 10 participants, randomised controlled trials (RCTs) and observational studies, in low-income and highincome countries were eligible for inclusion. Case reports, letters and commentaries were excluded. We also considered two National Institute of Health $(\mathrm{NIH})$ reports on HU treatment for SCD. ${ }^{10}{ }^{11}$ Although our focus was on children aged below 5 years, we also considered relevant studies which enrolled children up to 18 years of age as there is a paucity of data on younger children. The outcomes specified as 'critical' included: mortality, rates of hospitalisation and severe neurological events (cerebrovascular accident). Outcomes considered important were: morbidity (ie, pain episodes) and toxicity (see table 1). We also extracted data on additional relevant outcomes reported in the identified studies including treatment effect on $\mathrm{HbF}$ level and organ function (see tables 2 and 3). Three reviewers independently screened titles, abstracts and full articles, and applied the predefined study selection criteria to identify eligible studies.

\section{Data extraction}

Data were abstracted by a single reviewer and a co-investigator verified accuracy. Abstracted data included: study characteristics (eg, study design, settings), doses of $\mathrm{HU}$, duration of $\mathrm{HU}$ therapy and outcome measures (see web only table 5).

\section{Data synthesis}

There was heterogeneity due to differences in study designs (RCTs vs observational studies) and outcome measures, so statistical pooling of results was considered inappropriate. The results are therefore presented as a narrative summary.

\section{Quality assessment}

Assessment of the quality of evidence was done using the Grading of Recommendations Assessment, Development and Evaluation tool. ${ }^{18}$ This was done by two reviewers independently and disagreements resolved through discussion. The unique features of Grading of Recommendations Assessment, Development and Evaluation include: (1) explicit, comprehensive criteria for downgrading and upgrading quality of evidence ratings; (2) explicit evaluation of the importance of outcomes; and (3) clear separation of quality of evidence from the strength
Table 1 Summary outcomes for children receiving hydroxyurea for sickle cell disease

\begin{tabular}{|c|c|}
\hline Outcome & Effect \\
\hline \multicolumn{2}{|l|}{ Blood markers } \\
\hline Haemoglobin level & Not significantly different \\
\hline Percentage of fetal haemoglobin & Increased (very low quality evidence) \\
\hline \multicolumn{2}{|l|}{ Clinical outcomes } \\
\hline Pain crises & Decreased (low quality evidence) \\
\hline Hospitalisations & Decreased (low quality evidence) \\
\hline Blood transfusion therapy & Insufficient data \\
\hline Acute chest syndrome & Insufficient data \\
\hline Secondary stroke & $\begin{array}{l}\text { Decreased (very low quality evidence) } \\
\text { No effect (low quality evidence) }\end{array}$ \\
\hline \multicolumn{2}{|l|}{ Prevention of end organ damage } \\
\hline Spleen & $\begin{array}{l}\text { No significant difference (low quality } \\
\text { evidence) }\end{array}$ \\
\hline Kidney & $\begin{array}{l}\text { No significant difference (low quality } \\
\text { evidence) }\end{array}$ \\
\hline $\begin{array}{l}\text { Brain (transcranial Doppler } \\
\text { velocity) }\end{array}$ & Decreased (very low quality evidence) \\
\hline \multicolumn{2}{|l|}{ Mortality } \\
\hline Mortality & Decreased effect \\
\hline \multicolumn{2}{|l|}{ Toxicity } \\
\hline Neutropenia & $\begin{array}{l}\text { Mild to moderate (moderate quality } \\
\text { evidence) }\end{array}$ \\
\hline Leg ulcers & Insufficient data \\
\hline Thrombocytopenia & Insufficient data \\
\hline Anaemia & Insufficient data \\
\hline
\end{tabular}

of care recommendations. The approach classifies the quality of evidence into four categories: high, moderate, low or very low. The quality of evidence is taken into account in the narrative synthesis of findings.

\section{RESULTS}

Overall, we identified 98 studies from the searches and included 19 reports in this review (1 systematic review, ${ }^{7} 2$ multicentre RCTs $^{19}{ }^{20}$ and 16 observational studies inclusive of two NIH reports $^{10-16}{ }^{21-28}$ (figure 1 )). The majority of included studies were conducted in high-income countries $(n=11)$; only two studies were conducted in low-income and middle-income countries. The doses of HU were varied (range: $10 \mathrm{mg} / \mathrm{kg} / \mathrm{day}$ to $35 \mathrm{mg} / \mathrm{kg} /$ day). Control treatments were placebo (in one RCT) and standard treatment without HU.

\section{A. Systematic review}

The 2008 systematic review ${ }^{7}$ included 1 RCT $(n=25)$ and 22 observational studies (that included 15-225 participants and 3 case reports). Children studied ranged from ages 2-22 years. The authors concluded that there was high quality evidence suggesting that use of $\mathrm{HU}$ resulted in: reductions in hospitalisation events ( $\mathrm{n}=5$ studies, $56 \%$ to $87 \%$ decline in yearly rate); and increased total haemoglobin $(\mathrm{n}=16$ studies, $5 \%$ to $20 \%$ ) and $\mathrm{HbF}$ ( $\mathrm{n}=17$ studies, 93\% to $366 \%$ increase) in children with severe SCA. They also stated that there was moderate quality evidence suggesting that HU reduced painful crisis ( $\mathrm{n}=5$ studies). In addition, low quality evidence suggested that HU was associated with decreased transfusions (three studies) and neurological events (three studies), and improvement in splenic function (three studies). Common adverse events were of mild to moderate severity and included: mild to moderate neutropenia (500 to 


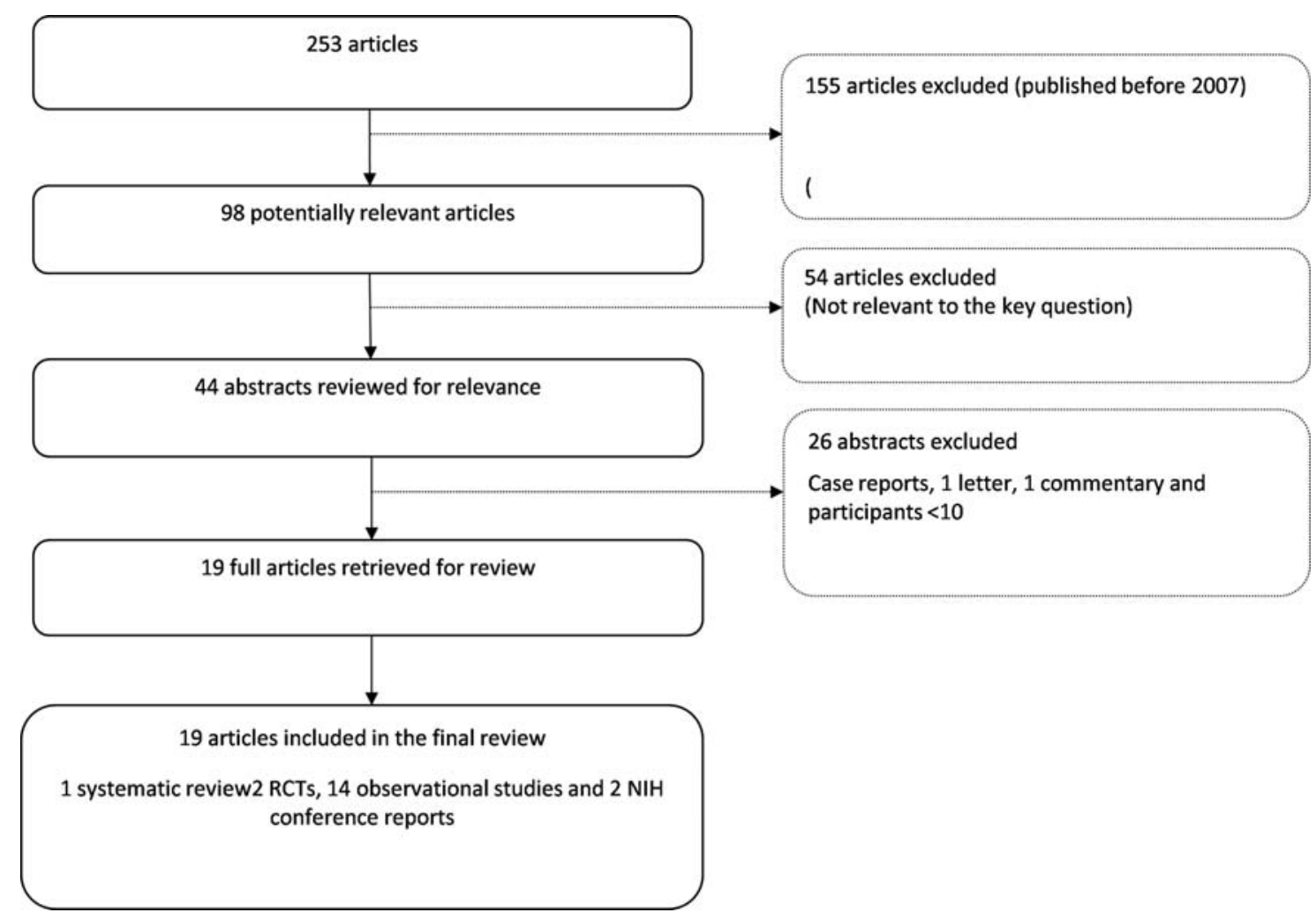

Figure 1 Flow diagram of the study selection criteria.

$<1500 / \mu \mathrm{L})^{3}$, mild thrombocytopenia $\left(<80 \times 10^{3} / \mu \mathrm{L}\right)^{3}$, severe anaemia (haemoglobin $<50 \mathrm{~g} / \mathrm{L}$ ), rash or nail changes and headache. Severe adverse events (eg, leukaemia or secondary malignancies) were rare and not clearly attributable to HU.

\section{B. Post systematic review RCTs and observational studies}

One double-blind $\mathrm{RCT}^{19}(\mathrm{~N}=193)$ was conducted in 13 centres in the USA. It enrolled children aged 9-18 months with HbSS (homozygous type of SCA) or $\mathrm{Hb} \mathrm{S} / \beta$-thalassaemia irrespective of clinical severity. HU was administered as a standard dose of $20 \mathrm{mg} / \mathrm{kg}$ without escalating to maximum tolerated dose. The primary end points were changes in spleen and renal function. There were no significant differences between the HU and the placebo groups in these end points: 19 of $70(27 \%)$ patients had decreased spleen function at exit in the HU group versus 28 of $74(38 \%)$ patients in the placebo group (mean difference $-11 \%$, $95 \%$ CI $-26 \%$ to $5 \%, \mathrm{p}=0.21$ ) and a difference in the mean increase in the diethylenetriaminepentaacetic acid glomerular filtration rate in the $\mathrm{HU}$ group versus the placebo group of $2 \mathrm{~mL} /$ $\min$ per $1.73 \mathrm{~m}^{2}, 95 \% \mathrm{CI}-16$ to $20, \mathrm{p}=0.84$. The quality of evidence for the reported outcomes was rated as low (table 2).

Data relevant to the critical and important outcomes that are the subject of this review are drawn from the two multicentre RCTs and 14 observational studies, and are summarised below.

\section{Mortality}

Two studies reported on this outcome; in the RCT there were no deaths in the 24 months of follow-up. ${ }^{19}$ Nzouakou et al ${ }^{22}$ $(n=123)$ reported four deaths in a retrospective cohort study during follow-up, though the patients had stopped taking HU 1-5 years before their deaths. The deaths were attributed to toxic shock, severe vaso-occlusive crises, heart failure and nonspecified cardiac failure.

\section{Hospitalisations}

There were no significant differences in hospitalisation rates between comparison groups in the RCT $(\mathrm{HR}=0.73$, 95\% CI 0.53 to $1.00, \mathrm{p}=0.05) .{ }^{19}$ However, in one retrospective longitudinal study $(\mathrm{n}=312)$ adherence to HU resulted in decreased risk of SCD-related hospitalisations $(\mathrm{HR}=0.65,95 \% \mathrm{CI} 0.43$ to $0.97, \mathrm{p}=0.035){ }^{12}$ in the 1 st year following initiation of HU. Nzouakou et al $^{22}$ reported a mean decrease of 13.4 days of hospitalisation under $\mathrm{HU}$ in comparison with the period before $\mathrm{HU}$ initiation $(p<0.0001)$ observed in 64 patients. Similarly in one prospective single-centre study $(n=47) \mathrm{HU}$ was associated with a decrease in mean hospitalisation days from 29.3 days/year (95\% CI 7 to 84 ) before HU to 3.2 days/year (95\% CI 0 to 15 ) after $\mathrm{HU}, \mathrm{p}<0.01$. $^{21}$

\section{Neurological events}

HU has been reported to prevent secondary stroke but not primary stroke in children. Ali et al ${ }^{16}(\mathrm{n}=43)$, reported that only one child in the HU group had clinical stroke recurrence, incidence rate 2/100 person-years, compared with 20/33 in the non-HU group, incidence rate $29 / 100$ person-years; HR 9.4, $95 \%$ CI 1.3 to $70.6, p=0.03$. Four observational studies ${ }^{13} 23-25$ reported data on other neurological end points: two ${ }^{13} 25$ of them reported on transcranial Doppler (TCD) velocity (elevated velocities have been shown to be associated with increased risk of stroke $)^{25}$. In one prospective pilot study $(n=14),{ }^{13}$ the average TCD values decreased with average reduction of 25.6 $\pm 27.6 \mathrm{~cm} / \mathrm{s}(95 \%$ CI 8.1 to $43.1, \mathrm{p}<0.01)$ in the right middle cerebral artery (MCA) and $26.8 \pm 32.6 \mathrm{~cm} / \mathrm{s}$ (95\% CI 6.1 to 47.6, $\mathrm{p}<0.05)$ in the left MCA following use of HU. In the second study, ${ }^{25} \mathrm{HU}$ resulted in a significant decrease in TCD velocity in the right MCA $(166 \pm 27 \mathrm{~cm} / \mathrm{s}$ to $135 \pm 27 \mathrm{~cm} / \mathrm{s}$, $\mathrm{p}<0.001)$ and the left MCA $(168 \pm 26 \mathrm{~cm} / \mathrm{s}$ to $142 \pm 27 \mathrm{~cm} / \mathrm{s}$, $\mathrm{p}<0.001)$. In one retrospective cohort study $(\mathrm{n}=52),{ }^{24} 96 \%$ of 
Table 2 Grade summary of findings for Wang et al $2011^{19}$

\begin{tabular}{|c|c|c|c|c|c|}
\hline \multirow[b]{2}{*}{ Outcomes } & \multicolumn{2}{|l|}{ Illustrative comparative risks* $(95 \% \mathrm{Cl})$} & \multirow[b]{2}{*}{$\begin{array}{l}\text { Relative effect } \\
(95 \% \mathrm{CI})\end{array}$} & \multirow{2}{*}{$\begin{array}{l}\text { No. of } \\
\text { participants } \\
\text { (studies) }\end{array}$} & \multirow{2}{*}{$\begin{array}{l}\text { Quality of } \\
\text { the evidence } \\
\text { (GRADE) }\end{array}$} \\
\hline & $\begin{array}{l}\text { Assumed risk } \\
\text { Placebo }\end{array}$ & $\begin{array}{l}\text { Corresponding risk } \\
\text { Hydroxyurea }\end{array}$ & & & \\
\hline $\begin{array}{l}\text { Spleen function } \\
\text { Spleen scan uptake }\end{array}$ & Moderate & & $\begin{array}{l}\text { Mean difference } \\
-11 \%(-26 \text { to } 5)\end{array}$ & $\begin{array}{l}144 \\
\text { (1 study) }\end{array}$ & 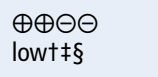 \\
\hline $\begin{array}{l}\text { Renal function } \\
\text { Mean DTPA GFR } \mathrm{mL} / \mathrm{min} \\
\text { per } 1.73 \mathrm{~m}^{2}\end{array}$ & $\begin{array}{l}\text { The mean renal function in the control } \\
\text { groups was } \\
\mathrm{mL} / \mathrm{min} \text { per } 1.73 \mathrm{~m}^{2}\end{array}$ & $\begin{array}{l}\text { The mean renal function in the } \\
\text { intervention groups was } \\
2 \text { higher } \\
\text { (16 lower to } 20 \text { higher) }\end{array}$ & $\begin{array}{l}\text { Mean difference } 2 \mathrm{~mL} / \mathrm{min} \\
\left.\text { per } 1.73 \mathrm{~m}^{2} \text { (-16 to } 20\right)\end{array}$ & $\begin{array}{l}133 \\
\text { (1 study) }\end{array}$ & $\begin{array}{l}\oplus \oplus \Theta \Theta \\
\text { lowt§ }\end{array}$ \\
\hline $\begin{array}{l}\text { Haematological data(HbF) } \\
\text { Percentage }\end{array}$ & $\begin{array}{l}\text { The mean haematological data at exit } \\
\text { in the control groups was } 17.1 \%\end{array}$ & $\begin{array}{l}\text { The mean haematological data at exit in } \\
\text { the intervention groups was } 22.4 \% \\
\text { (5.3\% higher) }\end{array}$ & $\begin{array}{l}\text { Mean difference } \\
6.7 \text { (4.8 to } 8.7)\end{array}$ & $\begin{array}{l}158 \\
\text { (1 study) }\end{array}$ & $\begin{array}{l}\oplus \oplus \Theta \Theta \\
\text { lowt§ }\end{array}$ \\
\hline $\begin{array}{l}\text { Pain episodes } \\
\text { (vaso-occlusive pain } \\
\text { episodes) } \\
\text { Number of events }\end{array}$ & $\begin{array}{l}\text { Study population } \\
773 \text { per } 1000 \\
\text { Moderate }\end{array}$ & $\begin{array}{l}583 \text { per } 1000 \\
(464 \text { to } 708)\end{array}$ & $\begin{array}{l}\text { HR } 0.59 \\
(0.42 \text { to } 0.83)\end{array}$ & $\begin{array}{l}193 \\
\text { (1 study) }\end{array}$ & $\begin{array}{l}\oplus \oplus \Theta \Theta \\
\text { lowt }\end{array}$ \\
\hline $\begin{array}{l}\text { Number of transfusions } \\
\text { Number of events }\end{array}$ & $\begin{array}{l}\text { Study population } \\
340 \text { per } 1000 \\
\text { Moderate }\end{array}$ & $\begin{array}{l}204 \text { per } 1000 \\
(125 \text { to } 329)\end{array}$ & $\begin{array}{l}\text { HR } 0.55 \\
(0.32 \text { to } 0.96)\end{array}$ & $\begin{array}{l}193 \\
\text { (1 study) }\end{array}$ & $\begin{array}{l}\oplus \oplus \Theta \Theta \\
\text { lowt }\end{array}$ \\
\hline $\begin{array}{l}\text { Acute chest syndrome } \\
\text { Number of events }\end{array}$ & $\begin{array}{l}\text { Study population } \\
186 \text { per } 1000 \\
\text { Moderate }\end{array}$ & $\begin{array}{l}71 \text { per } 1000 \\
(30 \text { to } 164)\end{array}$ & $\begin{array}{l}\text { HR } 0.36 \\
(0.15 \text { to } 0.87)\end{array}$ & $\begin{array}{l}193 \\
\text { (1 study) }\end{array}$ & $\begin{array}{l}\oplus \oplus \Theta \Theta \\
\text { lowt§ }\end{array}$ \\
\hline $\begin{array}{l}\text { Dactylitis } \\
\text { Number of events }\end{array}$ & $\begin{array}{l}\text { Study population } \\
433 \text { per } 1000 \\
\text { Moderate }\end{array}$ & $\begin{array}{l}142 \text { per } 1000 \\
(82 \text { to } 247)\end{array}$ & $\begin{array}{l}\text { HR } 0.27 \\
(0.15 \text { to } 0.5)\end{array}$ & $\begin{array}{l}193 \\
\text { (1 study) }\end{array}$ & $\begin{array}{l}\oplus \oplus \Theta \Theta \\
\text { lowt§ }\end{array}$ \\
\hline $\begin{array}{l}\text { Rate of hospitalisation } \\
\text { Number of events }\end{array}$ & $\begin{array}{l}\text { Study population } \\
866 \text { per } 1000 \\
\text { Moderate }\end{array}$ & $\begin{array}{l}769 \text { per } 1000 \\
(655 \text { to } 866)\end{array}$ & $\begin{array}{l}\text { HR } 0.73 \\
(0.53 \text { to } 1)\end{array}$ & $\begin{array}{l}193 \\
\text { (1 study) }\end{array}$ & $\begin{array}{l}\oplus \oplus \Theta \Theta \\
\text { lowt§ }\end{array}$ \\
\hline $\begin{array}{l}\text { Moderate neutropenia } \\
\text { Absolute neutrophil count } \\
\text { Follow-up: } 24 \text { months }\end{array}$ & $\begin{array}{l}\text { Study population } \\
186 \text { per } 1000 \\
\text { Moderate } \\
\text { High }\end{array}$ & $\begin{array}{l}460 \text { per } 1000 \\
\text { (295 to } 649)\end{array}$ & $\begin{array}{l}\text { HR } 3.0 \\
\text { (1.7 to } 5.1)\end{array}$ & $\begin{array}{l}193 \\
\text { (1 study) }\end{array}$ & $\begin{array}{l}\oplus \oplus \Theta \Theta \\
\text { lowt§ }\end{array}$ \\
\hline
\end{tabular}

the patients had stable MRI findings after HU while $28 \%$ of the study participants had MRI-identified silent brain ischaemia prior to use of HU. An additional non-inferiority randomised multicentre trial $(\mathrm{n}=161)^{20}$ compared standard treatment (transfusions/chelation, $\mathrm{n}=66)$ with alternative treatment $(\mathrm{HU} / \mathrm{phle}-$ botomy, $\mathrm{n}=67$ ) in children with SCA. The findings showed no benefit of $\mathrm{HU}$ on prevention of secondary stroke: there was no stroke on the transfusion/chelation arm but 7/67 (10\%) on the $\mathrm{HU} /$ phlebotomy arm (which was still within non-inferiority stroke margin), and no difference in the liver iron concentration in comparison with the baseline in the two arms.

\section{Pain episodes}

HU was associated with decreased frequency of pain events in four studies (one RCT and three observational studies). In the RCT, ${ }^{19} \mathrm{HU}$ significantly reduced pain episodes over 24 months of follow-up (177 events in 62 patients in the HU group vs 375 events in 75 patients in the control group, $p<0.002$ ) compared with placebo. Similarly, HU was associated with significant reductions in pain episodes in the two retrospective studies and one prospective study: Stallworth $e t a l^{26}(\mathrm{n}=523)$, (Rate ratio, $\mathrm{RR}=0.79,95 \%$ CI 0.71 to $0.89, \mathrm{p}<0.0001$ ); Candrilli et $a l^{12}$ $(\mathrm{n}=312),(\mathrm{HR}=0.66,95 \% \mathrm{CI} 0.47$ to $0.92, \mathrm{p}=0.0130)$ and Mellouli et $a l^{21}(\mathrm{n}=47),(21$ out of 38 patients treated with HU for recurrent crises ( $>$ three crises/year) had no further crises).

\section{Fetal Haemoglobin (HbF)}

Three studies (one RCT and two observational studies, $\mathrm{n}=213$ ) reported statistically significant increases in $\mathrm{HbF}^{13}{ }^{14}{ }^{19}$ In the RCT, ${ }^{19} \mathrm{HU}$ was associated with a higher mean exit concentration of $\mathrm{HbF}$ (by 5.3\%) compared with that in the placebo group $(\mathrm{p}<0.0001)$.

\section{Toxicity}

Three studies ${ }^{19} 2122$ reported on this outcome. The multicentre RCT reported that HU was associated with a significantly higher frequency of episodes of mild to moderate neutropenia that resulted in temporary treatment cessation (107 events in 45 
Table 3 Grade summary of findings tables for the observational studies ${ }^{12-17}$

\begin{tabular}{|c|c|c|c|c|c|}
\hline \multirow[b]{2}{*}{ Outcomes } & \multicolumn{2}{|c|}{ Illustrative comparative risks* $(95 \% \mathrm{Cl})$} & \multirow[b]{2}{*}{$\begin{array}{l}\text { Relative effect } \\
(95 \% \mathrm{CI})\end{array}$} & \multirow{2}{*}{$\begin{array}{l}\text { No. of } \\
\text { participants } \\
\text { (studies) }\end{array}$} & \multirow{2}{*}{$\begin{array}{l}\text { Quality of } \\
\text { the evidence } \\
\text { (GRADE) }\end{array}$} \\
\hline & Assumed risk & $\begin{array}{l}\text { Corresponding risk } \\
\text { Hydroxyurea }\end{array}$ & & & \\
\hline $\begin{array}{l}\text { Haematological data } \\
(\mathrm{HbF}) \\
\text { Percentage }\end{array}$ & Not estimable & Not estimable & $\begin{array}{l}\text { Significant increase in } \mathrm{HbF} \text { after } \mathrm{HU} \text { use } \\
\text { In one study the change was } 11.2 \text { ( } 7.1 \text { to } \\
15.4)^{13} \text { In another } \mathrm{HbF} \text { changed from } \\
19.8 \pm 6.9 \text { to } 24.4 \pm 6.3^{17}\end{array}$ & $\begin{array}{l}45 \\
\text { (3 studies) }\end{array}$ & $\begin{array}{l}\oplus \Theta \Theta \Theta \\
\text { very lowt }\end{array}$ \\
\hline $\begin{array}{l}\text { Pain episodes (vaso } \\
\text { occlusive pain events) } \\
\text { Number of events }\end{array}$ & $\begin{array}{l}\text { Study population } \\
\text { Moderate }\end{array}$ & & $\begin{array}{l}\text { RR } 0.79 \\
\text { (0.71 to } 0.89)\end{array}$ & $\begin{array}{l}523 \\
\text { (1 study) }\end{array}$ & $\begin{array}{l}\oplus \ominus \ominus \Theta \\
\text { very low } \neq\end{array}$ \\
\hline $\begin{array}{l}\text { Hospitalisation } \\
\text { Number of events }\end{array}$ & $\begin{array}{l}\text { Study population } \\
\text { Moderate }\end{array}$ & & $\begin{array}{l}\text { HR } 0.65 \\
(0.43 \text { to } 0.97)\end{array}$ & $\begin{array}{l}312 \\
\text { (1 study) }\end{array}$ & $\begin{array}{l}\oplus \Theta \Theta \Theta \\
\text { very low§ף }\end{array}$ \\
\hline $\begin{array}{l}\text { HRQL } \\
\text { PedsQL Score }\end{array}$ & $\begin{array}{l}\text { The mean HRQL using } \\
\text { pedsQL self report in the } \\
\text { control groups was } \\
69 \text { scale scores }\end{array}$ & $\begin{array}{l}\text { The mean HRQL using pedsQL self } \\
\text { report in the intervention groups } \\
\text { was } \\
75 \text { higher } \\
\text { ( } 62 \text { to } 86.4 \text { higher)** }\end{array}$ & $\begin{array}{l}\text { HU group }=75(62.0 \text { to } 86.4) \\
\text { No HU group }=69(54.1 \text { to } 79.9)\end{array}$ & $\begin{array}{l}191 \\
\text { (1 study) }\end{array}$ & $\begin{array}{l}\oplus \Theta \Theta \Theta \\
\text { very } \\
\operatorname{low}^{* *}, t \dagger, \neq \ddagger\end{array}$ \\
\hline $\begin{array}{l}\text { Neurological event } \\
\text { number of events } \\
\text { Follow-up: } 111 \\
\text { patient-years }\end{array}$ & $\begin{array}{l}\text { Study population } \\
606 \text { per } 1000 \\
\text { Moderate }\end{array}$ & $\begin{array}{l}1000 \text { per } 1000 \\
(702 \text { to } 1000)\end{array}$ & $\begin{array}{l}\text { HR } 9.4 \\
(1.3 \text { to } 70.6)\end{array}$ & $\begin{array}{l}43 \\
\text { (1 study) }\end{array}$ & $\begin{array}{l}\oplus \Theta \Theta \Theta \\
\text { very low§§ }\end{array}$ \\
\hline \multicolumn{6}{|c|}{ 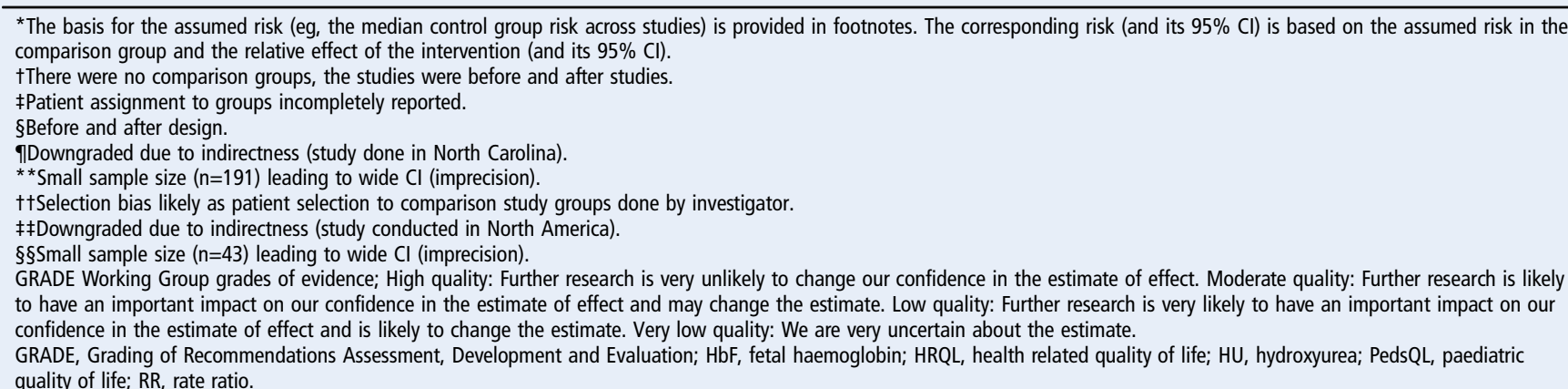 } \\
\hline
\end{tabular}

patients vs 34 events in 18 patients in the placebo arm over 24 months; HR 3.0, 95\% CI 1.7 to $4.1, \mathrm{p}<0.001$ ). Persistent or recurrent neutropenia (nine children in the HU arm vs five children in the placebo arm) led to a decrease in HU dosage to $17.5 \mathrm{mg} / \mathrm{kg} /$ day. One retrospective cohort study (without comparator data), ${ }^{22}(\mathrm{n}=123)$ of children on HU treatment reported that 41 patients $(33 \%)$ experienced 66 adverse events, including four deaths (described above), during a median follow-up of 2.8 years (range $0.02-10.5$; frequency $12 \%$ per patient-year). The most frequent event in this study was leg ulcers; some had cutaneous reactions such as skin dryness and some minor haematological disorders. The 66 adverse events did not require changing HU dose for 25 (38\%) episodes but led to dose reduction for $16(24 \%)$ others and to HU withdrawal for 21 (32\%). Mellouli et al $(n=47)$ reported one episode of severe thrombocytopenia with severe leucopenia that resolved after stopping $\mathrm{HU}$, another episode of pancytopenia was attributed to parvovirus infection.

Additional findings on adherence, health related quality of life outcomes and findings from the two NIH reports are summarised in web appendix 1 .

\section{DISCUSSION}

\section{Interpretation of results}

Adult studies are considered to provide strong evidence for the efficacy of $\mathrm{HU}$ with decreases in severe painful episodes, hospitalisations, number of blood transfusions and acute chest syndrome. ${ }^{10}$ The data also suggest that the risks of HU are acceptable in adults as compared with the risks of untreated
SCD ${ }^{11}$ with reduced mortality after 9 years of follow-up in those on treatment initiated for multiple vaso-occlusive crises. $^{6}$

The available evidence on the efficacy, effectiveness and safety of HU in childhood SCD is mostly from high-income countries and for children up to 18 years of age. Studies on children below 5 years are very limited, with only one recent RCT enrolling children $(n=193)^{19}$ from the age of $9-18$ months, yet this age group experiences mortality rates as high as 7.3 per 100 person-years of observation in African settings, with children below 5 years accounting for $70 \%$ of all deaths. ${ }^{29}{ }^{30}$ Furthermore, mortality remains high in the group of children (aged $>3$ years) who may benefit from HU therapy if initiated early in life. ${ }^{31}$ Dosages of $\mathrm{HU}$ used in childhood studies ranged from $10 \mathrm{mg} / \mathrm{kg} /$ day to $35 \mathrm{mg} / \mathrm{kg} /$ day. In most studies, HU was started at the lower dosage and escalated to maximum tolerated dose with continuous haematological monitoring to safeguard against potential neutropenia.

A consistent feature of these studies was the provision of high quality supportive care in addition to HU. Of specific relevance to low-income settings is the use of regular haematological monitoring. Thus in the RCT conducted in early childhood full blood counts were drawn every 2-4 weeks except for $\mathrm{HbF}$ which was obtained every 6 months. Results were used to identify mild to moderate neutropenia and guide treatment cessation until blood counts normalised. The consequences of continuing HU therapy in the presence of mild to moderate neutropenia when haematological monitoring is either not possible at all or based on much reduced sampling frequency, is not known. 
Table 4 Grade summary of findings for Ware et al $2012^{20}$

\begin{tabular}{|c|c|c|c|c|c|c|}
\hline Outcomes & $\begin{array}{l}\text { Comparator arm } \\
\text { Transfusions with chelation }\end{array}$ & $\begin{array}{l}\text { Intervention arm } \\
\text { Hydroxyurea with phlebotomy }\end{array}$ & $\begin{array}{l}\text { Relative effect } \\
(95 \% \mathrm{CI})\end{array}$ & $\begin{array}{l}\text { No. of } \\
\text { participants } \\
\text { (studies) }\end{array}$ & $\begin{array}{l}\text { Quality of } \\
\text { the evidence } \\
\text { (GRADE) }\end{array}$ & Comments \\
\hline $\begin{array}{l}\text { Secondary stroke } \\
\text { recurrence } \\
\text { recurrence rate } \\
\text { Follow-up: } 6 \text { months }\end{array}$ & \multicolumn{2}{|c|}{$\begin{array}{l}\text { Recurrence rate of } 0 \%, 0.0 \text { events per } 100 \text { patient years in } \\
\text { comparator arm versus recurrence rate of } 10 \%, 5.6 \text { events per } \\
100 \text { patient years in the intervention arm }\end{array}$} & Rate difference of 0.1 & $\begin{array}{l}161 \\
\text { (1 study) }\end{array}$ & $\begin{array}{l}\oplus \oplus \Theta \Theta \\
\text { lowt‡§ף }\end{array}$ & \\
\hline $\begin{array}{l}\text { Iron overload } \\
\text { Liver Iron concentration } \\
\text { mg/g dry weight liver } \\
\text { Follow-up: } 6 \text { months }\end{array}$ & $\begin{array}{l}\text { The median iron overload in } \\
\text { the control groups was } \\
17.3 \mathrm{mg} / \mathrm{g} \text { dry weight liver } \\
\text { (8.8-30.7 IQR) }\end{array}$ & $\begin{array}{l}\text { The median iron overload in the } \\
\text { intervention groups was } \\
17.2 \mathrm{mg} / \mathrm{g} \text { dry weight liver } \\
(10.0-30.6 \mathrm{IQR})\end{array}$ & $\begin{array}{l}\text { Change from baseline } \\
\text { (median (IQR) } \\
-2.2 \text { ( }-5.5 \text { to } 4.9 \text { ) in the } \\
\text { comparator group } \\
-1.2(-2.8 \text { to } 7.2 \text { ) in the } \\
\text { intervention group }\end{array}$ & $\begin{array}{l}161 \\
\text { (1 study) }\end{array}$ & $\begin{array}{l}\oplus \oplus \Theta \Theta \\
\text { low } \dagger \ddagger \S \uparrow \\
* *,+\dagger\end{array}$ & \\
\hline
\end{tabular}

${ }^{*}$ Children enrolled in the study were above 5 years old yet interested in data of children below 5 years.

tThe use of hydroxyurea overlapped at some point with transfusions during the dose escalation.

‡The study setting is in high-income setting where there is thorough laboratory monitoring in contrast with low-income setting that the study question focuses on.

$\S$ Some point estimates in the study have wide Cls.

ISample sizes in both arms were small (hydroxyurea with phlebotomy, $n=67$; while transfusions with chelation, $n=66$ ).

GRADE Working Group grades of evidence; High quality: Further research is very unlikely to change our confidence in the estimate of effect. Moderate quality: Further research is likely

to have an important impact on our confidence in the estimate of effect and may change the estimate. Low quality: Further research is very likely to have an important impact on our

confidence in the estimate of effect and is likely to change the estimate. Very low quality: We are very uncertain about the estimate.

GRADE, Grading of Recommendations Assessment, Development and Evaluation.

Given these caveats, available low quality evidence suggest that HU used in children, if adequately adhered to by patients and appropriately monitored, may be associated with reduced rates of hospitalisation and reduced frequency of painful vaso-occlusive crises. On the other hand low quality evidence suggests that $\mathrm{HU}$ is not beneficial in preventing secondary episodes of stroke ${ }^{20}$ (table 4). Data on longer term adverse events are very limited, few children under 5 years of age have been studied and follow-up times in the summarised studies was short.

\section{Weaknesses of the current literature}

The majority of the studies summarised in the 2008 systematic review $^{7}$ and published since this review, were observational (22 studies and 14 studies, respectively) increasing the possibility of bias and confounding. Further, most had retrospective designs with assignment to $\mathrm{HU}$ based on patient or physician preference and there was substantial heterogeneity in outcomes measured. Only one RCT enrolling children from infancy and early childhood has been published to date. Additional limitations of summarised evidence from a Kenyan perspective and when considering guidelines for those aged less than 5 years include: (1) indirectness of evidence: most studies were done in USA and enrolled children upto 18 years of age and adults; (2) very limited data on critical outcomes and; (3) imprecision as most studies had small numbers of participants (only two studies, both retrospective, ${ }^{12} 26$ enrolled more than 300 patients).

\section{Implications for policy, practice and future research}

Use of HU in children under 5 years of age with SCD who have vaso-occlusive crises and dactylitis and whose treatment can be appropriately monitored appears reasonable although the quality of evidence supporting this position is low to moderate. $^{32}$ However, it is not yet clear if treatment as a prophylactic therapy can be recommended for children of this age with SCD, especially in low-income settings where the ability to monitor therapy may be limited.

Additional RCTs are needed to assess the effectiveness and safety of HU in children below 5 years in Africa ideally using pragmatic regimens with low frequency haematological monitoring. Further studies are also needed to establish the optimal dosing of HU. Such studies are justified as HU is relatively cheap. In Kenya, in the private sector, the average price for a $500 \mathrm{mg} \mathrm{HU}$ capsule is approximately US $\$ 0.47,{ }^{33}$ which translates to treatment cost per month of about US\$14. However, alternative formulations will be required for children and monitoring will increase treatment costs. Formal cost-effectiveness analyses to examine costs and health gains of $\mathrm{HU}$ are therefore needed to inform decisions on the feasibility and desirability of scaling up treatment in low-income settings such as Kenya.

\section{CONCLUSION}

Our findings suggest that HU, the only available disease modifying therapy, might improve haematological outcomes (HbF), decrease hospitalisation rates and reduce pain episodes. Very low quality data exist on the effects of $\mathrm{HU}$ in children below 5 years in low-income countries where capacity for haematological monitoring is very limited. Further pragmatic RCTs with linked cost-effectiveness analyses are needed to address this gap.

Correction notice The license of this article has also changed since publication to CC BY 4.0.

Acknowledgements We would like to thank Nyokabi Musila for her input in the review question formulation. This work is published with the permission of the Director of KEMRI.

Contributors MM, NO, JK and ME designed the review methodology. MM, GK and ME conducted the literature searches. MM and ME screened studies for inclusion. MM, NO and ME extracted data, appraised study quality and synthesised study findings. MM wrote the first draft. All the authors participated in the interpretation of results and writing of the manuscript.

Funding SIRCLE collaboration by the Kenyan Consortium for National Health Research; Wellcome Trust.

Competing interests $\mathrm{MM}$ and JK were supported by funds awarded to the SIRCLE collaboration by the Kenyan Consortium for National Health Research. NO was supported by funds from a Wellcome Trust Strategic Award (\#084538). ME is supported by a Wellcome Trust Senior Fellowship (\#097170). The funding source had no role in the conduct of the review and writing of the report.

Provenance and peer review Not commissioned; externally peer reviewed.

Open Access This is an Open Access article distributed in accordance with the terms of the Creative Commons Attribution (CC BY 4.0) license, which permits others to distribute, remix, adapt and build upon this work, for commercial use, provided the original work is properly cited. See: http://creativecommons.org/ licenses/by/4.0/ 


\section{REFERENCES}

1 Report, J.W.-M.O.D.M., Management of birth defects and hemoglobin disorders. 2006:9.

2 Scott JA, Berkley JA, Mwangi I, et al. Relation between falciparum malaria and bacteraemia in Kenyan children: a population-based, case-control study and a longitudinal study. Lancet 2011;378:1316-23.

3 Neville AK, Panepinto JA. Pharmacotherapy of sickle cell disease. 18th Expert Committee on the selection and Use of Essential Medicines2011 21st to 25th March.

4 Rogers DW, Clarke JM, Cupidore L, et al. Early deaths in Jamaican children with sickle cell disease. Br Med J 1978;1:1515-16.

5 Leikin SL, Gallagher D, Kinney TR, et al. Mortality in children and adolescents with sickle cell disease. Co-operative Study of Sickle Cell Disease. Pediatrics 1989;84:500-8.

6 Steinberg MH, Barton F, Castro 0, et al. Effect of hydroxyurea on mortality and morbidity in adult sickle cell anemia: risks and benefits up to 9 years of treatment. JAMA 2003;289:1645-51.

7 Strouse JJ, Lanzkron S, Beach MC, et al. Hydroxyurea for sickle cell disease: a systematic review for efficacy and toxicity in children. Pediatrics 2008;122:1332-42.

8 Ministry of Health. Clinical guidelines for management and referral of common conditions at levels 4-6:Hospitals. 2009; III:259-61.

9 Haynes RB, Wilczynski NL. Optimal search strategies for retrieving scientifically strong studies of diagnosis from Medline: analytical survey. BMJ 2004;328:1040.

10 Brawley OW, Cornelius LJ, Edwards LR, et al. National Institutes of Health Consensus Development Conference statement: hydroxyurea treatment for sickle cell disease. Ann Intern Med 2008;148:932-8.

11 Brawley OW, Cornelius LJ, Edwards LR, et al. NIH consensus development statement on hydroxyurea treatment for sickle cell disease. NIH Consens State Sci Statements 2008;25:1-30.

12 Candrilli SD, O'Brien SH, Ware RE, et al. Hydroxyurea adherence and associated outcomes among Medicaid enrollees with sickle Cell Disease. Am J Hematol 2011;86:273-7.

13 Thornburg CD, Dixon N, Burgett $S$, et al. A pilot study of hydroxyurea to prevent chronic organ damage in young children with sickle cell anemia. Pediatr Blood Cancer 2009;52:609-15.

14 Vasavda N, Badiger S, Rees D, et al. The presence of alpha-thalassaemia trait blunts the response to hydroxycarbamide in patients with sickle cell disease. $\mathrm{Br} J$ Haematol 2008;143:589-92.

15 Thornburg CD, Calatroni A, Panepinto JA. Differences in health-related quality of life in children with sickle cell disease receiving hydroxyurea. J Pediatr Hematol Oncol 2011:33:251-4.

16 Ali SB, Moosang M, King L, et al. Stroke recurrence in children with sickle cell disease treated with hydroxyurea following first clinical stroke. Am J Hemato 2011;86:846-50.
17 Italia K, Dipty J, Sushma G, et al. Hydroxyurea in sickle cell disease-a study of clinico-pharmacological efficacy in the Indian haplotype. Blood Cells Mol Dis 2009:42:25-31.

18 Guyatt HG. Rating quality of evidence and strength of recommendations. BMJ 2008:336:924-6.

19 Wang WC, Ware RE, Miller ST, et al. Hydroxycarbamide in very young children with sickle-cell anaemia: a multicentre, randomised, controlled trial (BABY HUG). Lancet 2011;377:1663-72.

20 Ware RE, Helms RW. Stroke With Transfusions Changing to Hydroxyurea (SWiTCH). Blood 2012;119:3925-32.

21 Mellouli F, Bejaoui M. The use of hydroxyurea in severe forms of sickle cell disease: Study of 47 Tunisian paediatric cases. Elsevier J 2008:24-8.

22 Nzouakou R, Bachir D, Lavaud A, et al. Clinical follow-up of hydroxyurea-treated adults with sickle cell disease. Acta Haematol 2011;125:145-52.

23 Greenway A, Ware RE, Thornburg CD. Long-term results using hydroxyurea/ phlebotomy for reducing secondary stroke risk in children with sickle cell anemia and iron overload. Am J Hematol 2011;86:357-61.

24 Hankins JS, Helton KJ, McCarville MB, et al. Preservation of spleen and brain function in children with sickle cell anemia treated with hydroxyurea. Pediatr Blood Cancer 2008;50:293-7.

25 Zimmerman SA, Schultz WH, Burgett $\mathrm{S}$, et al. Hydroxyurea therapy lowers transcranial Doppler flow velocities in children with sickle cell anemia. Blood 2007:110:1043-7.

26 Stallworth JR, Jerrell JM, Tripathi A. Cost-effectiveness of hydroxyurea in reducing the frequency of pain episodes and hospitalization in pediatric sickle cell disease. Am J Hematol 2010;85:795-7.

27 Thornburg CD, Calatroni $A$, Telen $M$, et al. Adherence to hydroxyurea therapy in children with sickle cell anemia. J Pediatr 2010;156:415-19.

28 Tripathi A, Jerrell JM, Stallworth JR. Clinical complications in severe pediatric sickle cell disease and the impact of hydroxyurea. Pediatr Blood Cancer 2011;56:90-4.

29 Makani J, Cox SE, Soka D, et al. Mortality in sickle cell anemia in Africa: a prospective cohort study in Tanzania. PLoS ONE 2011;6:e14699.

30 Rahimy MC, Gangbo A, Ahouignan G, et al. Effect of a comprehensive clinical care program on disease course in severely ill children with sickle cell anemia in a sub-Saharan African setting. Blood 2003;102:834-8.

31 Yanni E, Grosse DS, Yang Q, et al. Trends in Pediatric sickle Cell Disease-Related Mortality in the United States, 1983-2002. J Pediatr 2008;154:541-5.

32 Manwani D. Commentary on: Hydroxycarbamide for very young children with sickle cell anaemia: no effect on the primary outcomes of spleen or kidney function, but evidence for decreased pain and dactylitis, with minimal toxicity. Evidence Based Med [Commentary] 2012;17:37-8.

33 http://www.pharmacydirectkenya.com (accessed 11 Apr 2012). 